\section{Animals and Plants of the Ancient} Maya, by Victoria Schlesinger (351 pages, March 2002), serves as a field guide to 100 species of plants and animals that were known to the ancient Maya of southern Mexico and Central America. Schlesinger provides the Spanish and Yucatec Mayan words for each species; notes on identification, habitat, range, similar species, and endangered status; and an essay on the natural history of each plant or animal, its cultural significance to the Maya, and its importance or use today. The Maya considered screech-owls, for example, as birds of death and their howls as messages from the underworld, but women frequently wore headdresses made from owl feathers. $\$ 70.00$. University of Texas. ISBN 0-292-77759-0.

The Balkan Wars, by André Gerolymatos (297 pages, March 2002), attempts to make sense of the culture of violence that has characterized the states of southeastern Europe and is little understood in the West. Beginning with a comparison of the 1389 Battle of Kosovo and the assassination of the Archduke Ferdinand in 1914, Gerolymatos sweeps through 600 years of history and myth to analyze the ethnic hatred that erupts periodically from Greece to Croatia. Provides a good supplement to Ivo Andric's famous 1959 novel, The Bridge on the Drina. \$28.00. Basic. ISBN 0-465-02731-8.

For those wanting to explore ancient Balkan history, The Early Slavs, by P. M. Barford ( 416 pages, November 2001), is a thorough archaeological, linguistic, and literary historical survey of life in Eastern Europe and Russia from the 5 th to the 10th century. Much of Barford's source material has not been available in English, making this well-illustrated and wellmapped volume a valuable contribution. $\$ 39.95$. Cornell University. ISBN 0-8014-3977-9.

The Devil on Screen, by Charles P. Mitchell (337 pages, February 2002), provides a detailed appraisal and synopsis of 95 fearure films in which Satan, Lucifer; Beelzebub, Mephistopheles, Little

George M. Eberhart is senior editor of American Libraries; e-mail: geberhart@ala.org
Nicky, or other devilish manifestations make a significant appearance. All are available on video or DVD. Mitchell's commentary is insightful, and he offers notable quotes from each of the films for flavor: "Do you have $\$ 3.47$ ? I left my purse in the underworld," says

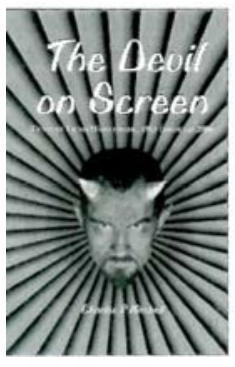
Elizabeth Hurley as the Devil in Bedazzled (2000). \$49.95. McFarland. ISBN 0-7864-1049-3.

Genealogical Research on the Web, by Diane K. Kovacs (194 pages, January 2002), offers much useful information for both beginning and advanced genealogists. Although focused on Web resources, Kovacs cautions that the Internet is probably not the first place to start family research and provides a chapter on how to network with living family members. Librarians may wish to register with the book's companion Web site at http://www. kovacs. com/genbook/genbook.html to download patron or staff training materials for Web-based workshops. $\$ 55.00$. Neal-Schuman. ISBN 155570-430-1.

\section{Havana in My Heart: 75 Years of Cu-} ban Photography, edited by Gareth Jenkins (192 pages, May 2002), brings together 125 black-and-white photographs of Havana scenes and events taken by Cuban photographers. Most have not been seen outside of Cuba. The work of internationally recognized photographers Alberto Korda, Constantino Arias, and Osvaldo Salas is represented, as well as images from other Havana photographers and archives that depict street scenes, musicians and other artists, Santeria

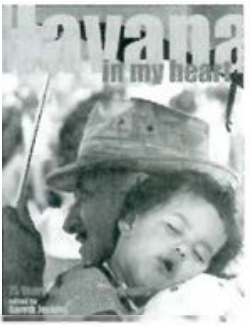
ceremonies, Carnival, and images from the 1959 Revolution (including photos of Fidel Castro with Ernest Hemingway and Yuri Gagarin). 
Perhaps the most poignant are scenes from the marketplaces, streets, bars, and music halls that are the heart of the city. $\$ 29.95$. Chicago Review. ISBN 1-55652-439-0.

Jack the Ripper: An Encyclopedia, by John J. Eddleston (304 pages, October 2001), rates as one of the easier-to-use Ripper sourcebooks. British scholar Eddleston organizes the entries into alphabetical sections on the victims, the witnesses, the police investigators, others who played a part, a chronology, descriptions of Jack, letters he supposedly wrote, myths and errors, locations, the suspects (each assigned a number referring to the likelihood of his being the Ripper), qualitative reviews of other Ripper books (generously noting any errors of fact the author makes), other resources, and a summary in which the author lets loose with his own assessment of the case. Well-researched, with minimal distractions and subjectivity. $\$ 75.00$. ABC-Clio. ISBN 1-57607$414-5$.

\section{London Booksellers and American Cus-} tomers, by James Raven (522 pages, May 2002), explores in great detail the book pur-

("Complementary and alternative medicine" continued from page 589)

links to find a homeopathic practitioner. $A C$ cess: http:/ www homeopathic. org.

- Research Council for Complementary Medicine. Access: http://www rccm. org.uk/index.htm.

\section{Consumer health protection sites}

- National Council Against Health Fraud (NCAHF). NCAHF, a private, nonprofit organization, tackles health fraud as a public health concern. Their Web site features occasional papers, position papers and task force reports, testimony given before Congress, and consumer information statements on specific treatments and therapies. Most of the articles on the site are researched and written by physicians, nurses, and other health care professionals. Also on the site is access to a speakers bureau, an electronic newsletter, links to similar sites, and breaking news. Access: http:// www.ncahf.org/.

- Quackwatch: Your Guide to Health Fraud, Quackery, and Intelligent Deci- chases and correspondence of the Charleston (S.C.) Library Society from 1748 to 1811 . The archives of the society provide a unique glimpse into both the transatlantic book trade and the role of library societies in the diffusion of cultural and intellectual pursuits throughout the South during the latter half of the 18 th century. Particularly useful for collections in the history of the book trade. $\$ 59.95$. University of South Carolina. ISBN 1-57003-406-0.

\section{The Oxford Companion to American}

Law, edited by Kermit L. Hall ( 912 pages, July 2002), explains in clear language the concepts, terms, practices, agencies, individuals, crimes, and proceedings that make up American jurisprudence. Nearly 500 essays, written by some 300 contributors, provide authoritative commentary directed at general readers, students, journalists, and nonlegal scholars. The topics are extremely diverse, ranging from the Salem Witchcraft Trials and Busb v. Gore (2000) to consumer law, torts, governance, taxation, evidence, and criminal procedure. An excellent introduction that serves as a one-volume first step to legal research. $\$ 65.00$. Oxford University. ISBN 0-19-508878-6.

sions. Quackwatch, a nonprofit corporation created to battle health fraud and promote consumer health awareness, was founded by Stephen Barrett, M.D., in 1969. The Web site consists of links to articles and information on suspicious treatments, diagnoses, and therapies as well as individuals, companies, and publishers who support them. The articles are written by medical, scientific, or legal specialists, and many include lists of references. Another section of Quackwatch includes information about questionable advertisements and non-recommended sources of health advice. The site also includes information on where to report health fraud and how to be an intelligent health consumer. Access: http://www.quackwatch.com.

\section{Notes}

1. Helen Lippman, "Can complementary and conventional medicine learn to get along?" Business \& Health (2001) 9: 15-19.

2. Ibid.

3. National Center for Complementary and Alternative Medicine, "What is Complementary and Alternative Medicine?" http://nccam. nih.gov/health/whatiscam/. 